\title{
African Political Economy and The Quest for Free Market: Challenges and Prospects
}

\author{
Abdulrahman Adamu* \\ Department of Political Science, Federal University, Gusau Zamfara State, Nigeria
}

\begin{abstract}
It is germane to state that communism to a market economy in the former Soviet Union and Eastern Europe has not gone down well in many aspects that could lead to growth and development in Africa but its movement in China and Vietnam has performed tangibly beyond expectation. Worthy to note is that Africa witnessed high level of stagnation in the beginning of the century of the post-colonial period and in recent time, there has been a competition between population and poverty reduction; the percentage in poverty has gone down, but the absolute numbers of impoverished have increased. The ostensible behind this piece is to assess the efforts of African states in their quest for achieving free market economy. This paper applied qualitative method of data collection while globalization theory was used as a basis of its analysis. The paper reveals that globalization has been a mixed blessing in this aspect as it plays an important role both in the successes and failures. It concludes that these dramatic economic events have not surprisingly been accompanied by a high level of intellectual ferment. It recommended among others that, new policies for alleviating poverty in order to ensure growth and development, such as conditional cash transfers and micro-lending as introduced be implemented to the fullest to ensure poverty is actually reduced to minimal level.
\end{abstract}

Keywords: Africa; Political economy; Development; Free market; Globalization; Economy

\section{Introduction}

Africa is endowed with human and material resources yet, it faces serious economic challenges and that has hindered in no small way the spate of the continent's development. The continent is regarded as third world because of its inability to compete in terms of development with the so-called Western world. When we think of Africa, we typically conjure the images of poverty, starvation, civil war, and most recently disease [1]. Since the 1960s, a large number of African countries went through devastating civil wars; while some including Angola, Mozambique and Nigeria, seem to be on the mend, the democratic republic of Congo and Sudan remain perilously unstable [2]. Some African countries end up with dictator leadership which really affects the growth and development of African states. Poverty, over population, unemployment, technological backwardness, lack of infrastructural facilities, low GDP, low income earning, low life expectancy, dependent economy are other vises distorting the African continent. Political crisis and leadership problem are worth mentioning in African case. Kwame Nkrumah the first president of Ghana asserted that Africa only got political independence but not economic independence. The economy of post-colonial African society is dependent on the foreign aid for survival. The economic problem of Africa could be attributed to globalization. For instance, many believe it is a curse to Africa, while to some it is a blessing to Africa. The negative trend of globalization has further deepened the gap between Africa and developed world. With its emergence Africa became impoverished. The activities of the international financial institutions of the world have also compounded to the problem. The structural adjustment policy introduced by the world bank to remedy Africa economic problems end up extorting Africa resource for the benefit of the western states.

\section{Literature Review}

\section{Conceptual clarification}

Free market is concerned with non-participation of government in the economic affairs of the state; individuals are legal entity who determines the forces of supply and demand. Some scholars are of the opinion that a free market contrast with regulated market in which government intervenes in supply and demand through various methods such as tariffs used to restrict trade and protect the economy. In free market economy, prices of goods and services are set freely by the forces of demand and supply and are allowed to get to their point of equilibrium without intervention by the government policies. Other scholars argued that a free market is not necessarily deregulated. Thus, free markets are commonly associated with capitalism within a market economy. Therefore, what is capitalism? Capitalism is conceptualized as a socio economic and political system whereby the factors of production, distribution and exchange are owned and controlled by private individuals.

\section{Theoretical framework}

Globalization is the best theory to the understanding of the economic and the quest for free market economy in Africa. Globalization stressed a universal culture of trade, business and economic activities. The removal of tariffs and restrictions as stress by the globalization theory among nations of the world would lead to economic boost. Also, deregulation, privatization, foreign investment, markets economic, technological transfer are panacea for economic growth and development of the developing nations.

\section{Nature of African economy}

The economies of African countries in 2007 experienced growth significantly above the global average rates. The top countries in 2007

*Corresponding author: Abdulrahman Adamu, Department of Political Science, Federal University, Gusau Zamfara State, Nigeria, Tel: +2348039190666; E-mail: abduladamu6@gmail.com

Received June 22, 2017; Accepted July 25, 2017; Published July 29, 2017

Citation: Adamu A (2017) African Political Economy and The Quest for Free Market: Challenges and Prospects. Review Pub Administration Manag 5: 221. doi:10.4172/2315-7844.1000221

Copyright: (c) 2017 Adamu A. This is an open-access article distributed under the terms of the Creative Commons Attribution License, which permits unrestricted use, distribution, and reproduction in any medium, provided the original author and source are credited. 
include Mauritania with growth at $19.8 \%$, Angola at $17.6 \%$, Sudan at $9.6 \%$, Mozambique at $7.9 \%$, and Malawi at $6.7 \%$. Other fastest growing economy includes Rwanda, Mozambique, Chad, Niger, Burkina Faso, Ethiopia. Zimbabwe, DR Congo, republic of Congo and Burundi are slow growing economy [3], argued that trade between Africa and China stood at USA \$166 billion in 2011 .

It is also argued that infrastructure investments contributed to more than half of Africa's improved growth performance between 1990 and 2005 and increased investment is necessary to maintain growth and tackle poverty. Kingdoma, in 2011 opined that in Africa, it is argued that to meet the MDGs by 2015, infrastructure investments would need to reach about $15 \%$ of GDP (around, \#93 billion a year). Infrastructural development in Africa has also limit the economic expansion of African states. Lack of infrastructure creates barriers for African businesses $[4,5]$. Such infrastructures are paved highways, railway, airports, and other constructions.

Corruption in Africa consists primarily of extracting economic rent and moving the resulting financial capital overseas instead of investing at home. Governments are politically unstable in Africa and new governments often confiscated their predecessor's assets. Growing evidence is showing that foreign aid has made the country poorer [6]. Today, Africa faces the problem of attracting foreign aid in areas where there is potential for high income from demand.

Intra-African trade has been slowed by protectionist policies among countries and region. Despite this trade between countries belong to common market...a particularly strong economic region, six-fold over the past decade up to 2012 [7]. Ghana and Kenya, for example, have developed markets within the region for construction materials, machinery, and finished products, different from the mining and agricultural products that make up the bulk of their international exports [7]. A situation whereby Africa export crops to the west while millions on the continent starve has been blamed on developed countries including Japan, the European Union and the United States. These countries protect their own agricultural sectors with high import tariffs and offers subsidies to their farmers [8], which lead to over production of commodities. The result of this is that the global price of such product is continually reduced until Africans are unable to compete, except for cash crops that do not grow easily in the north climate [4,5]. Agricultural technology is another area of concern for African economy. Increased investment in African agricultural technology in general has the potential to reduce poverty in Africa $[4,5]$. The Nigerian, South African and Ugandan governments have targeted policies to take advantage of the increased demand for certain agricultural products and plan to stimulate agricultural sectors. The Africa union has planned to heavily invest in African agriculture (AU support crucial agricultural progress). Africa is richly endowed with mineral reserves and ranks first or second in quantity of world reserves of bauxite, cobalt, industrial diamond, phosphate rock, platinumgroup metals (PGM), vermiculite, and zirconium. For many African countries, mineral exploration and production constitute significant parts of their economies and remain keys to future economic growth.

Manufacturing activities is another phase in which African states are trying to develop. Nigeria in recent years has been embracing industrialization, it currently has and indigenous vehicle manufacturing company [9], that manufactured rapid transit buses, trucks and SUVs with an upcoming introduction of cars [9]. Nigeria also has few electronic manufacturers like Zinox, the first branded Nigerian computer and electronic gadgets manufacturers [10].

\section{Trends to African economic development}

Globalization is seen to be the yardstick for Africa problems while other considers it as a blessing to Africa. Globalization has its negative and positive impact on the life of Africa. Mclean and McMillan globalization is about the universal process or set of processes which generate a multiplicity of linkage and inter-connection which transcend the state and societies which make up the modern world system. In other word, we can deductively conclude that the goal of globalization is to move from pre-modern to modernity of the world as a system. Therefore, by this assertion we concluded that globalization is a continue process that has no static point.

According to Tabb, globalization is a comprehensive term for the emergence of a global society in which economic, political, environmental and cultural events, in one part of the world quickly comes to have significance for people in other part of the world. This means that, globalization is a development in one side and transferring the development to other parts which are undeveloped. He asserts globalization describes the growing economic, political, technological, and cultural linkage that connects individuals, communities, businesses, and government around the world. This means that globalization is beyond an economic event. It also states a relationship or the influence of political environmental and cultural events between one part of the world and others.

There have been debate concerning the nature and mode of globalization. In this case globalization can be referred to activities. For some scholars, this activity seems to have favored one side of the coin and disfavor the other. Soro, defined globalization as a free movement of capital and the increasing domination of national economic by global financial market and multi-national corporation. According to Modibbo [11], globalization is the intensification of the domination of the economic, political, security, military, and social cultural affairs of the world by industrial capitalism aided and facilitated by the electronic and telecommunication resolution under the hegemony of the USA and it's allied in Europe's as well as Japan. This definition suggested that globalization is beneficiary to the world industrial capitalism and not to Africa. Meaning globalization can be seen as the new world order which has been imposing in favor of Europe's and its agencies. For Modibbo [11], globalization can also be observed technically to be a form of colonization but in different dimension through imperialism. For him the unification of world is to conform to the standard of the European nations.

According to Asobie, globalization is essentially the universality of capitalism in its speculative variety. For those who conceived globalization at the expense of the under developing countries believed that united nation agencies such as IMF, IBRC, WB, NATO, WHO, MNCS and WTO etc. are established in favor of America and European capitalism. They also view it as form of continuous colonization, slavery of the under develop world in another dimension. Those who conceived it as a development to Africa see it as a new opportunity to developing countries and greater access to developed country markets and technology transfer which has brought about improvement and productivity, output, employment and improvement in living standard as reported by Angappapillai. The central notion of globalization is liberalization which emphasized the dismantlement of barriers in international trade and capital movement through the integration of national economic into world economy.

\section{Impact of globalization in Africa}

The impact of globalization in Africa can be viewed from two angles. 
That is negative and positive effects. As cited by Moddibo, the main nitty-gritty of this academic mission is on the effect of globalization on the third world countries, but before we to step further it's very important to highlight the basic facts that implementation of the global tenets are not done in a vacuum, it is carried out by some agencies and organizations such as the World Bank, IMF, World Trade Organizations, and world leaders etc. The negative impact of globalization has made African economy to be dependents. To him, the developing countries are taking the concept as a dangerous process of exploitation which is making the rich countries richer and big International Corporation are getting bigger and richer at the expense of the poor once. He asserts further that globalization is a one-sided beneficiary phenomenon. It's a development for the capitalist but to African states it is underdevelopment and dependency. The fact remains that the benefits are unevenly distributed and its cost are uneven when seen in the light of developing countries. According to UNDP human development report (1999:25), both in concept and in practice, for every positive aspect of globalization there is negative side. While globalization has positive innovative and dynamic aspects, it also has negative, disruptive and marginalizing aspect. The opening of borders has also led to the decline and decay of national industries and enterprises because the activities of the multi-national companies render the local industries inferior and incompetents. Globalization has induced illicit in drugs, prostitution, and pornography, human trafficking, national cultural identities are also under threats [11].

In the area of ecological degradation, African environments are in serious trades, dumping of dangerous waste and depletion of the environment by MNCs. The activities of MNCs have affected the life, productiveness of agricultural production in Africa. Most of these corporations are not meeting up with their social responsibilities. For example, gas-flaring, poor waste management, youth restiveness among others. Most African countries cannot compete with the global players because our product is fake or sub-standard that has no international recognition thereby hampering the rate of our export and also dealing with our local currencies through globalization policies. That means globalization policies are geared towards subordinating African product to that of international standard with the aim of devaluating currencies of African state making her more dependent.

The evolution of globalization has also affected the political system of African state. Most policies of African leaders are teleguided by the western world. The American, Britain and France are the international players of globalization. No developing countries of the world take international decision without their approval. According to Sheikh [12] globalization led to the emergence of worldwide financial market and batter access to global external financing for borrowers. He also added that it should be noted that globalization is not as many would wish to present it as a recent phenomenon, nor one which Africa is unfamiliar or its consequences, setting aside for now the more ancient histories and through endless series of economic transactions which over a century linked Europe, Asia, Africa and the Americans. Globalization is an unending process that can be traced to the slave trade era to the colonial era and now globalization.

He therefore asserts further that the imperial domination and exploitation is an unending process but in another dimension. Saying that among the earliest manifestation of globalization was the slave trade between West Africa and Britain, Europe and elsewhere. Industrialization became possible because of the exploitation of the slave and other sources for cheap labor that feed the system at extremely low cost. Morrissey and Filatotchev [13] opined that reducing trade barriers does not mean that it does not introduce other barriers that constrain the capacity of marginalized countries to benefit from globalization. Their view is a critic to the definition of globalization which entails the removal of tariff for free trade. To them, globalization heavily favor in the direction of debt settlement rather than African development. The neo-liberal globalization initiatives also tended to favor the advanced capitalist countries rather than the debtor African countries. Abdullahi concluded that in the developing world, particularly Africa, the phenomena of the slavery, colonialism and globalization although historically belonging to different era but are connected. They form part of one big economic construct. That is expansion and maintainers of the capitalist system. To him, current manifestation of globalization therefore does not reflect a clear break for past but rather a continuation of realities previously created. In terms of passivity of the concept of globalization, it has brought about great political development and change to African states. The emergence of the universal democratic political system has produced a good governance in Africa which is to promote representative government, free press, rights of citizen etc. globalization has also turned the world into a global village, because many African states are embracing the global system of telecommunication.

Globalization has brought about the increase rates in private sector participation in the social economic development in most African countries. Because private sector is the main engine in development process [11]. It has also brought about free economy which is regarded as the ultimate form of capital accumulation in the word of Adam Smith. Globalization has also boost trading activities in many African states. Globalization cannot be said to be the only trends to African economic problem, other trends includes, government crises, corruption, failed policies, unemployment etc.

\section{Africa's quest for free market economy}

There can be no economic development in African countries until there emerge modernizers, powerful enough to sweep aside existing patronage structures, patrimonialism, petty tribalism and other cobwebs from the past that hinder creativity and wealth creation [14]. Free market economy is the modern and widely system that is needed to transform Africa economy and to ensure development. It is a contemporary system that facilitates economic growth and effective capacity expansion. Africa must abandon the weak economic structure and shift to a mode that will classify them among developed nations of the world. These reforms allow producers to greatly benefit from export boom, increasing incomes and boosting productivity through capital investment [15]. Africa has all the natural and human resources to be successful in agriculture and in economic development [16]. In the absence of these changes Africa can only hope for minimum or little growth and economicdependenton external conditions that willcontinue to frustrate the socio-economic and political life of Africa. No amount of macroeconomic policies, trade liberalization and privatization that can engender rapid and sustainable internal growth in the absence of an appropriate cultural environment for development [14], thereby concluding that "Africa redemption lies with Africans". Africans have the ability to decide whether to progress or not. Africa needs open markets, free trade both among its constituent nations and other developing nations, and the removal of ideological blinders [16].

Despite economic, political and social problem of Africa, the free market approach was incorporated by some few African countries. Societies have turned around and succeeded after passing through a period of vicious conflict and ruthless violence [15]. Rwanda and Nigeria are good examples. Since the 1994 phenomenon, the political 
and social situation has stabilized, making possible together with free market reforms, a sustained economic expansion in the relatively peaceful environment. The constant social ethnic tension ended in 1994, the economy of Rwanda sharply contracted by about $50 \%$ that year, but the recovery was quite fast and solid, with GDP growing at $35 \%$ per year in 1995 . The economy grew an average $6.6 \%$ per year from 1994 to 2010, substantially higher than the sub-Saharan African average. In 2001 Rwanda inhabitant lived on an average of 50 cents a day. Today, this figure has risen to $\$ 1.50$ a day. For the last five years poverty has been drastically reduced in Rwanda from almost $57 \%$ to $45 \%$ of the population. Paul Collier a British development economist also acknowledged that Rwanda had been able to achieve three key goals; rapid growth, sharp poverty reduction, and reduced inequality. On the other hand, Nigeria has also recorded little changes despite the current recession. Local farmers have much to eat and to sell to get more income. The prices are determined by the local farmers who also deal directly with exporter. This has raised the income level of local farmers in Nigeria. The economic growth in Rwanda has been primarily driven by liberalization in the agricultural sectors mainly coffee and tea, the country main exports [15]. In 2012, Rwanda is ranked $45^{\text {th }}$ in business regulation, after been $148^{\text {th }}$ in the last four years. Rwanda is also ranked $3^{\text {rd }}$ among African nations in the heritage foundation/wall street journal index of economic freedom. The premise behind Rwanda economic transformation is liberalization, with the most important of change being the registry of property, protection of investors and market openness among African countries. Advocates of free market economy argue that, a free market economy is the ideal economic system needed for national wealth and prosperity. They seek for the non-intervention of government in the economic affairs of the state. The school advocates for private ownership of the means of production. They also argued, for effective economic development and growth, foreign investment should be encouraged, tariffs should be discouraged and the existence of an open market.

In countries where state control the economy, opposition is displaced, no competition to production, distribution and exchange, because opposition and competition are not allowed, a free market economy provides for diffusion of wealth and power. Free market economy also provides higher rate of growth [2]. For example, between 1966 and 2006, Botswana average annual growth rate was $7.22 \%$ among the world highest, its income per capita adjusted for inflation and purchasing power parity rose from $\$ 671$ in $1966-\$ 10,813$ in 2005 [2]. State-regulation in several African nations can prevent their own exports from becoming competitive. Jane Shaw suggests that protectionism operates in tandem with heavy state intervention combining to depress economic development. Farmers subject to import and export restrictions...exposing them to higher market volatility and fewer opportunities [17]. Governmental intervention suppresses competition in the markets, resulting in competition being driven out of the market. As competition is driven out of the market, farmers innovate less and grow less food further undermining economic performance. The African union is the largest international economic grouping on the continent. The confederation goals include the creation of free trade area, a custom union, a single market, a central bank and a common currency. The current plan is to establish an African economic community with a single currency by 2023 [18]. It was not until the late 1990s that the government of Rwanda liberated the coffee sector. The reform removes legal requirements and made it possible for farmers to freely trade with buyers from any part of the world [15]. Boudreaux cited in 2012 [15] that liberalization not only improves the economic opportunities and potential of the people, it also enhances social cooperation and cohesion. He therefore concluded that, for Rwanda to be sustained in the long run, the country will need to keep increasing economic freedom and removing barriers to productive activity.

In spite of all the praise's accord to free market economy, it has also had some limitations to the African economy. For instance, in the 1980s and 1990s, SAP may have opened up African markets to foreign competition, but it also led to the closure of countless small and mediumsized enterprises at the local level and at the same time, the privatization of previously state-run led to massive lay-offs without social security [19]. The free market restructuring of national economies over recent decades has had a particularly dramatic effect on the agricultural sector in many African countries. A lot of small scale producers are forced to migrate since they cannot compete with large industrialized producers, resulting to unemployment.

Truly speaking, Africa still has plenty of problems and its development is still fragile [20]. Market panacea has not really solved Africa's economic ills. Over ten years, most African states are still waiting for the promise take-off. Most of them are struggling to recover to per capita income level which manifest in the 1970s. This is debilitating as a result of continued meddling the economic affairs of the state without good policies.

It should also be noted that foreign aid to some extent could help African states to get to the promised land but the government's conduct, directing, and control of these funds has been a problem. These funds are always diverted into pockets of politicians, public office holders and the elites. African leaders often depend on these funds to enrich themselves and leaving the masses to surfer what they must. A very good example of this is the SAP in Nigeria which could not yield positive impact on the nation economy because of mismanagement. Undoubtedly, the bank (IMF/World Bank) is correct in criticizing African governments for engaging in activities that have no growth potentials and no poverty reduction [14]. Other factors that have undermined economic reforms or limited their effectiveness include corruption in high places, political instability and lack of wealth creation culture there are nations in Africa and elsewhere that have relatively sound market oriented macroeconomic and trade policies, yet remain mired in economic failure and inefficiency [14]. For example, since 1995, Nigeria has achieved remarkable progress in macroeconomic stability and trade liberalization, yet its economic prospects have not improved. Zambia undergone privatization programmed yet, the country battled for her economic recovery.

\section{Conclusion and Recommendations}

Despite the attitudes of the international financial institutions towards African state as claimed by some analysts, the fact still remain that their objectives have helped in developing African economy to its contemporary form and nature. Shifting of blames on foreign aids, SAP, IMF, World Bank etc. would not be a panacea. If blames are leveled against external forces, what about the internal forces such as corruption, failed policies, mismanagement and frauds? Free market economy is in line with the notion of capitalism and capitalism has come to stay. It is a modernized method and system of economic development and growth. It can lead Africa to the desired state because the African countries are not ripe for socialism. Thus, free market is the best solution for Africa economic challenges. Interestingly, if agricultural sector is boosted it will increase production that can lead to industrializationandsubsequentlyleadtotechnologicaladvancementand this will in turn increase the efficiency of economic activities in the Africa. Globalization has also played a positive role in the development of 
contemporary African economy. Although, some might disagree that it is a curse to African society. The fact is that, the lack of cognizance by our political office holders and government officials to comprehend the globalization goals have really affected African economy. Government of African states needs to be proactive in formulating and implementing economic policies and programmes. For instance, if the developed nations refuse to open their boarders for African goods African boarders should as well remain closed for foreign products. African economy would attain boost if government free the economy.

Poverty is a current phenomenon devouring the African society to the core. Most African hardly survives on a square meal a day. This resulted to the poor economic performances of African states and the failure of the governments to formulate and implement genuine policies that can remedy such condition. The failure of previous poverty eradication programmes can be attributed to poor management, lack of continuity and administrative lag because government officials often time used the programmes for their own benefits. Government should adopt a pro-agricultural policy to counter the economic deficiency of the African states. Local producers of agricultural products should be allowed to operate directly and government should only provide insurance to this local farmer. Given the room for local producers to determine prices and trade directly with foreign investors would create room for more participation in the agricultural sectors which would reduce and if possible eradicate poverty in African countries. Liberalization, foreign investment, privatization, deregulation etc. need to be adopted. Individual ownership and freedom to produce, distribute, and exchange will be the highest form of wealth accumulation for Africa.

\section{References}

1. Neil OT (2015) Sub-Sahara Africa: A model of free market growth, Africa.

2. Tupy ML (2010) Africa needs free market economies. Global post, Africa.
3. King M (2012) China Africa trade Boom: The Journal of commerce (JOC Group INC).

4. Saul JJ, Leys C (1999) Sub-Sahara Africa in global capitalism: Monthly review.

5. Magdoff $F(2013)$ Twenty-first-century land grabs: Accumulation by agricultural disposition, monthly review, 65 .

6. Dambisa M (2009) Why foreign aid is hunting Africa: The Wall Street Journal, Africa.

7. UNECA (2012) Economic report on Africa, 45-47.

8. Gerald C (2008) The Betrayal of Africa. Ground wood Books: 93.

9. Chuchwuma (2013) Innoson cars will sell for N1 million. Abuja Inquirer, Nigeria, Africa.

10. Emma O (2013) Zinox introduces tablet range of computers, plans commercial launch, Africa.

11. Modibbo AS (2008) Globalization and its effect on Third World Countries in Nasarawa. J Polit Sci 1.

12. Sheikh AA (2010) Globalization, global financial meltdown and the Nigerian economy: Nigerian Acad Manage J, 4.

13. Morrissey O, Filatotchev L (2000) Globalization and trade: the marginalize economies. The Journal of Dev Stud, 37.

14. Obadina T (1999) Between free market orthodoxy and African reality. African business information services.

15. Oro AM (2012) Rwanda's economic success: How free markets are good for poor Africans. Economic trends report, Africa.

16. Laurson JF, Kempt J (2009) Africa's free market solution. Forbes Media LLC Africa 2016, 51.

17. Jane S (2004) Overlooking the obvious in Africa. Econ Journal Watch 1: 1-10. 18. BBC News (2006) Profile: African Union.

19. Parsons A (2010) Unemployment and the free market in Africa: Business in Africa magazine.

20. Lynn M (2014) Africa's rapid growth is to down to industry and free markets. BST 16, UK 